\title{
Conducting Qualitative Research in the Environment of People with Intellectual Disabilities: An Analysis of Adopting the Interpretative Paradigm and the Usefulness of the Grounded Theory Methodology
}

\begin{abstract}
The article concerns the methodological and theoretical aspects of research carried out in the environment of intellectually disabled people. The issues of intellectual disability pose a challenge for researchers; individuals with an intellectual disability constitute a specific group, the research of which requires an interpretative approach, that is, open and flexible research methods. Therefore, the main stress in the article is on proving the usefulness of the interpretative perspective, along with the advantages of adopting the grounded theory methodology to research this category of people. These approaches make it possible to adjust the research strategy to the characteristics of the explored research area. They allow for in-depth analysis of empirical data and thus create conditions for an accurate depiction of the researched environment. Making reference to research on the environment of intellectually disabled people, the usefulness of grounded theory methodology procedures was assessed in a broader context of research conducted in the interpretative paradigm.
\end{abstract}

Keywords:

disability, qualitative research, interpretative paradigm, grounded theory methodology (GTM)

1 Economy and Sociology Faculty, University of Łódź, Poland.

E-MAIL: jakub.niedbalski@uni.lodz.pl ORCID: https://orcid.org/0000-0002-2803-7628 


\section{INTRODUCTION}

Intellectual disability, although not immediately named that way or properly recognized, has accompanied humanity since time immemorial. Changes in the world view, civilizational development, and an increase in the level of knowledge regarding disability issues mean that our way of understanding what it really is have changed over time. Various historical sources report cases of people from different social environments, classes, and social strata, whose behavior deviated from the generally accepted standard. It is hard to accurately determine how many events described in this manner resulted directly from factors that are currently recognized as symptoms of intellectual disability. Nevertheless, interpreting such descriptions and reconstructions based on those descriptions made using contemporary scientific methods and specialist knowledge allows us to presume that they were indeed examples of intellectual disability (Niedbalski, 2009, p. 199). The development of modern techniques and diagnostic tools has made it possible to determine the mental health and intellectual level of an individual with a level of precision previously unknown. Furthermore, the contemporary understanding of intellectual disability has been strongly determined by a scientific interpretation of what is, on the one hand, believed to be normal, and on the other, extranormative, but justified and supported by the academic discourse. This leads to reflection and the search for answers to the following question: Have we now reached a point where it is possible to say for certain what is within an intellectual standard and what is different from it? We can give an affirmative answer, to some extent, but then we should limit ourselves to the proverbial "here and now". The changeability of perceiving an intellectual disability in time and social space makes us question the strict approach to the concept of the interpretative universalism of an intellectual standard. The visible relativism leaves open the notion of intellectual disability, while at the same time, it makes it difficult to grasp and define unambiguously (Niedbalski, 2009, p. 199). Therefore, can the following statement answer the question of what intellectual disability is? - It is what we interpret a mental dysfunction to be at a given time. And if it is, what kind of factors and conditions will determine a particular understanding of handicap? When will they become a source of particular interpretations? It would certainly be worthwhile discussing this topic in a broader extent. However, the task I undertook in this article is not to seek answers to such questions, although tempting, but to analyze the research process which would allow for the implementation of such an objective (Niedbalski, 2009, pp. 199-200). 
A person interested in problems of intellectual disability becomes forced to deal with various difficulties that appear at almost every stage of their research work. Each phase of the research, including field exploration related to collecting empirical data, is a challenge. The environment of people with an intellectual disability is a specific field of research that requires not only a flexible approach but also an adjustment of the research strategy to the cognitive and perceptive abilities of the intellectually disabled people (see: Cytowska, 2012, pp. 146-147). Therefore, a person who undertakes research on individuals with disabilities requires a particular sensitivity, an appropriate methodological toolkit, and technical preparation. At the same time, such a researcher should be fully aware of the difficulties that await them as well as the character and specificity of the environment of people with disabilities. Only such an attitude and full reflection may bring fruit in the form of proper and reliable research (see: Żyta, 2011, p. 24). However, this specificity and the uniqueness of the environment of people with disabilities mean that a researcher can never be sure of the results of their undertaking. These difficulties, combined with uncertainty about the final result, mean that research in which people with an intellectual disability participate is not only risky, in some sense, but also extremely demanding (Niedbalski, 2009, p. 200).

This paper attempts to identify the above-mentioned problems that accompany research into intellectually disabled people. It will also prove that the principles of conduct, the explanations of a given phenomenon or social process that is based on the adopted methods, and the theoretical background that is used may help a researcher to deal with the challenges they face. Reference is made to the interpretative paradigm and the interconnected qualitative research methods, analyzing the usefulness of the grounded theory (GT) methodology and the theory of symbolic interactionism.

The presented notions result from studies of the literature of the subject (Ramik-Mażewska, 2018; Żuraw, 2014; Cytowska, 2012; Żyta, 2011). They are also derived from the author's personal experience, which is based on research into the order of interactions between personnel and intellectually disabled charges who are residents of a social welfare home (Niedbalski, 2013). Hence, in my considerations, I focus on the procedures of a specific research method (GT) and the basis of the selected theoretical background rooted in the interpretative paradigm adopted in the research into the institutionalized care of intellectually disabled individuals. However, I would like to look at these problems from a broader perspective of qualitative research and stress their usefulness in the analysis of social aspects of intellectual disability. 


\section{THE PRAGMATIC BASIS OF RESEARCH INTO PEOPLE WITH INTELLECTUAL DISABILITY}

What can be considered indispensable in the scientific community is the comprehensive pluralism of thoughts and beliefs, which is, at the same time, a driving force for ongoing debates. This also concerns researchers of social sciences, who express very different beliefs and opinions which apply to even the most basic ontological, epistemological, and methodological assumptions about the surrounding reality. On the one hand, the richness of the diversity and never-ending discussions stimulate reflections and contribute to the development of science. On the other, however, they are the reason for numerous unnecessary controversies (Niedbalski, 2009, p. 201). There are many situations when such misunderstandings occur, and this is related to relativism prevailing in sociology. At the same time, the interpretation and analysis of all kinds of social phenomena are often subjected to different paradigmatic assumptions. This is a more complex problem, and the number of planes on which we deal with antagonisms occurring in this context seems to be extensive. It requires a separate and broader elaboration than allowed by this article.

Without going into the ontological and epistemological disputes on the distinction between the normative and interpretative paradigms, I would only like to draw attention to a different understanding of the qualitative and quantitative methods based on the above-mentioned paradigms. According to the normative paradigm, qualitative research is, in a way, an introduction to the quantitative measurement of phenomena. Meanwhile, according to the interpretative paradigm, phenomena are fundamental when analyzing and interpreting the collected data, as they are a basis to describe and explain a section of the social reality that is interesting to us (Konecki, 2000, p. 16). A phenomenon that ascribes an autonomous role to qualitative research can be observed in the context of the schools of phenomenology, ethnomethodology, or symbolic interactionism, among others, all of which originate from the interpretative paradigm. At the same time, each "school of interaction theory" has developed its own set of rules, principles, and assumptions, distinguishing it from the others, although they all belong to the same paradigm. The same applies to the relationships of particular interpretative theories with a methodological basis of research (Konecki, 2000, p. 17).

Each school, throughout its development, was somehow naturally connected ${ }^{2}$ to a particular research method. In the case of symbolic interactionism, the methodol-

2 The relationship between the theory and methodology of research often results from the joint development of both on the basis of one scientific "school", or shaping based on the authors' 
ogy of the grounded theory gradually became increasingly more important (see: Konecki, 2000). However, it should be noted that regardless of which "interaction" theory and research method we are dealing with, all of them are closely related to a particular basis of ontological and epistemological nature, which is rooted in a common interpretative paradigm. ${ }^{3}$ A common feature that connects all of these approaches is to render the viewpoints of participants of a researched group into an axis of analysis, as well as to focus on describing and interpreting everyday practices and knowledge on the subject of the research (Flick, 2010, p. 22). And this seems particularly appropriate when we want to give the floor to those who live on the margins of social life on a daily basis (Żuraw, 2014, p. 152). At the same time, emphasizing the fact that the reality we live in, thus, the reality of disabled individuals, is shaped by people in a specific community, allows us to discover the multiplicity, diversity, and complexity of the perspective that constructs the phenomenon of disability in our cultural circle (Rzeźnicka-Krupa, 2009, p. 74). The way we determine the social status of disabled individuals, how we look at those people, what we see and how we interpret it, create a certain research sphere. At the other extreme, for people with disabilities, it is accompanied by the sphere of discovering the area of self-perception, their own disability, experiencing this disability, and perceiving their own place in life and in the world (Rzeźnicka-Krupa, 2009).

According to Philip M. Ferguson, Dianne L. Ferguson, and Steven J. Taylor (1992), interpretativism in relation to disability research is not just another way of researching or another methodology. It is a perspective that allows us to see the previously underestimated contextuality of our knowledge and beliefs, which can have a significant impact on the social status of people with disabilities and their place in society. The interpretative orientation provides many opportunities to discover what disability is in culture and how it is experienced by the disabled individuals themselves (Cytowska, 2012, pp. 146-147). This happens because - as stressed by Joanna Rzeźnicka-Krupa (2009, pp. 73-74) - the research centers on a disabled human who is different in two ways. They are different as the Other, standing in the space of interpersonal relationships in the whole separateness of its essence, the inner world of experiences and sensations, and "different" in social perception, because of their distinctness related to disability (Rzeźnicka-Krupa, 2009, pp. 73-74).

investigations, adopting a certain methodology in their pioneering works and based on specific theoretical assumptions, thus creating a platform for interrelationships (Niedbalski, 2009).

3 According to Elżbieta Hałas (2005), there is currently no homogeneous interpretative sociology (the author uses the term 'interpretative') which suggests that we are dealing with not one but multiple variations. 
It must also be remembered that people with disabilities belong to groups that are marginalized in social life. They are often outsiders in the world of fully capable people, while their condition and identity are defined through the prism of disability (Danforth \& Navarro, 1998). The qualitative research adopted as part of the interpretative approach allows us to effectively recognize such "socially disadvantaged" groups and allows them to express themselves and their needs, and to take the voice from people who are listened to far less often (Cytowska, 2012, p. 147; cf. Podgórska-Jachnik, 1995). In this context, interpretative studies into the phenomenon of disability may, for example, pertain to those individuals who, as a result of a specific meaning being assigned to disability, are isolated from society to varying degrees (Rzeźnicka-Krupa, 2009, p. 76).

Furthermore, the interpretative perspective encourages researchers to seek answers, but it also allows them to reconstruct the basic question of what we understand disability to be. Instead of asking about the nature or essence of disability, it seems more important to ask the following questions: What does it mean to experience disability? And how is it experienced? This is how we ask about a certain context within which the construct of the reality of the disabled is built upon. In such a perspective, we are not trying to discover the nature of disability - as stated by Rzeźnicka-Krupa (2009, p. 78) - but rather it is an experience that is waiting to be described; it is a social and cultural creation composed of various experiences that await recognition.

Therefore, the notion of disability is that it is a product of a complex interaction between personal and contextual processes of creating meaning, and the knowledge on intellectual disability is construed and distributed according to procedures and mechanisms that have the character of social knowledge (Zakrzewska-Manterys \& Gustavsson, 1997, p. 26). The notion of disability functioning in a social space is, therefore, not just a term describing a certain state of affairs, but also a notion whose understanding incorporates values and evaluations, hidden postulates, and camouflaged labeling. In other words, the discussed notion is entangled in a world of senses and meanings that are polysemic, imprecise, and changeable, regarding time and circumstances (Zakrzewska-Manterys \& Gustavsson, 1997, p. 26).

Such an understanding of disability has its roots in the social interactionism and sociology of the Chicago school. Handicap is defined here through reference to meaning that is ascribed to various kinds of physical and intellectual deviations. The implications that symbolic interactionism has for research into deviations were presented by, among others, Erving Goffman (2008 [1963]). The best-known 
theory arising from this perspective is the theory of stigmatization. ${ }^{4}$ As Söder puts it (1989, p. 119),

a label may arise from the perspective of the labeler, it may be treated as neutral, descriptive or as a scientific diagnosis but actually it is something more. It places a person in a category that is filled with social meanings and prejudices [...]. A personality somehow solidifies in the form of handicap (cf. Zakrzewska-Manterys \& Gustavsson, 1997, pp. 12-13).

Therefore, disability is not a social fact, but it is produced by society, which ascribes an individual's actions and behaviors with the label of intellectually disabled person (Zakrzewska-Manterys, 2003, p. 110). ${ }^{5}$ Such an approach to this term suggests that it embraces features that are perhaps not significant or necessary for an appropriate description of a person, but they are especially clear and characteristic, and they point to the fact that the person deviates from standards of "normality" or "typicalness", and does not fulfill those criteria (Zakrzewska-Manterys, 2003, p. 108). Very often, characteristic criteria that may provide a basis to differentiate totally different people - as Elżbieta Zakrzewska-Manterys writes (2003) - are all lumped together, paying attention only to the fact that they do not fit the social criterion of being "normal”. The scope of phenomena regarded as normal varies across different societies, depending on cultural, economic, and historical factors. Hence, as Ferguson, Ferguson and Taylor (1992, p. 296) argue, the interpretative paradigm teaches us to ask not about what a given term means, but how it is used by those who use it to define other people.

4 The concept of labeling (social stigmatization), which arises from the theory of deviations, makes it possible to understand the mechanism of creating barriers that hinder the functioning of intellectually disabled people in society (cf. Żółkowska, 2004, p. 281).

5 The concept of intellectual disability is a very diverse and capacious category. The following are distinguished here: medical definitions based on etiology and pathogenesis; behavioral, characterizing mental disability from the point of view of psychiatric processes, and legal-administrative based on practical criteria. The definitions that are nowadays often referred to in the literature (see: Ramik-Mażewska, 2018; Podgórska-Jachnik, 2014) include the one from the International Classification of Functioning, Disability and Health (ICD-10), according to which the intellectual disability is described as an inhibition or incomplete mental development, expressed primarily in the impairment of skills that manifest themselves during the developmental period and constitute the overall level of intelligence. In turn, in the Diagnostic and Statistical Manual of Mental Disorders (DSM-5), intellectual disability is defined in two ways: as a fundamental deficit in learning and thinking capacity. The most recent definition created by the American Association on Intellectual and Developmental Disabilities (AAIDD), on the other hand, emphasizes that intellectual disabilities are characterized by a significant reduction in intellectual functions and, at the same time, in adaptation functions. 
Throughout my research, I myself experienced that - apart from being a biological, psychophysical, and medical phenomenon - disability is also a "social phenomenon". It was a conceptual product created in everyday interactions between a disabled individual (resident) and the fully-capable participants of the researched environment (personnel). For example, the personnel who take up a job in a social welfare home usually had an imprinted image of a disabled person based on cognitive schemes they had internalized in the socialization process. In other words, they had a certain vision of what a person with a disability is, what they can do and what they cannot do, and thus what to expect from them. This vision referred to social stereotypes and prejudices according to which a nondisabled individual perceives people with various psychophysical dysfunctions as not self-reliant, but dependent on others and incapable of dealing with everyday matters. However, it was often the case that the social welfare home residents contradicted this stereotype, gradually contributing to a change in the negative image of the whole category of disabled individuals. At the same time, the non-disabled individuals who created this environment built their concept of disability based on organizational practices and everyday rituals taking place in a given facility. In this way, the organizational and discourse practices taking place within a given environment contributed decisively to them reconstructing the identity of a disabled person.

While performing my own research in the environment of intellectually disabled individuals, to be able to research and understand the specificity of the analyzed processes, I chose symbolic interactionism as the theoretical framework, where the social world is a construct, and language is its biggest and most significant tool (Blumer, 1969). According to the theoretical assumptions, how we look at reality and ourselves is a reflection of the surrounding social world. At the same time, this world cannot be understood in basic categories, in terms of causal connections, or analyzed by applying universal laws to social events (Charmaz, 1994). This arises from the fact that human actions are based on social meaning, such as intentions, motifs, beliefs, principles, and values (Hammersley \& Atkinson, 2007). The significance of the processes of interpreting objects and phenomena, and defining oneself and situations in a manner appropriate for a given role is emphasized in symbolic interactionism (Becker, 1953, 1963). According to this approach, the nature of an individual - including an intellectually disabled person - is creative, while their reality is dynamic and changeable. Therefore, it is impossible to discover the "rights" that govern human behavior without considering the symbolic character of how individuals perceive the world and the symbolic character of interactions that take place between social actors (Blumer, 1969). 
Reconstructing the processes, interactions, interpretations, and actions that are meaningful for the individuals that create them requires familiarization with the actor's point of view, to grasp everything that is meaningful to them, and to analyze each phenomenon in the context of those meanings (Blumer, 1969). Therefore, taking into account the theoretical references mentioned above, in the research carried out in the environment of the disabled individuals, I referred to the subjective perspective of the researched individuals, transforming their own point of view into a basis for the construction of theoretical generalizations (cf. Wołowicz-Ruszkowska, 2013). This is how I attempted to grasp both the reflective character of the people who are actors during their individual development, as well as group and supra-individual relationships and interactions. All of this was connected to the processuality and situationality of each symbolic interaction, which was supported by GTM (Denzin, 1972). Therefore, in order to carry out research designed in such a way, I referred to the theoretical basis of the interpretative theory, and I used the methodological tools present in the grounded theory methodology.

\section{GROUNDED THEORY METHODOLOGY AND RESEARCH INTO INTELLECTUAL DISABILITY}

The theoretical perspective of interpretativism has become particularly close to researchers who represent qualitative research. This can be seen, for example, in the relationship between the "sociology of interactions" and the theory of symbolic interactionism and the grounded theory methodology that exists within its framework. As stressed by Krzysztof Konecki (2000, p. 24), a researcher using grounded theory methodology is somehow entangled in the grid of notions which are characteristic of the interpretative paradigm.

Looking at the genesis of the development of grounded theory methodology, we can see that it results from reflections and analyses that flow from empirical research on the work of health care and social welfare institutions, among others. This approach had its roots in the research of work organization and processes, while studies into psychiatric institutions (Strauss et al., 1964) and organizations educating medical professions (Becker et al., 1961) provided the basis for the development of this methodology.

The relationship of grounded theory methodology with symbolic interactionism and the character of the research (regarding the problems of psychiatric and medical institutions, among others), which became a starting point for the devel- 
opment of grounded theory methodology, determine the proximity and connection of an ideological, substantive and of course methodological nature with my own research on the institutionalized forms of care of intellectually disabled individuals which I refer to in this paper (see: Niedbalski, 2013).

\section{THE REQUIREMENT TO LIMIT INITIAL ASSUMPTIONS AND MAINTAIN THE CONTEXT OF THE DISCOVERY}

One of the fundamental principles for the researcher's conduct that the creators of the grounded theory methodology strongly emphasize is minimizing the pre-conceptualization of their own research intentions (Konecki, 2000, p. 26; Frankfort-Nachmias \& Nachmias, 2001, p. 313). In other words, a researcher who decides to use grounded theory methodology should - as far as possible - beware of constructing initial assumptions which could make him become a "theory slave" (Niedbalski, 2009, p. 204). At the same time, it needs to be borne in mind that the requirement to minimize pre-conceptualization is not the same as the researcher separating himself from any theoretical basis or already held knowledge in the field of research that they are interested in (which would be difficult to execute regarding existing knowledge or experience) (Żuraw, 2014, p. 155). Following this requirement, in the initial phase of the research, we should first of all try to focus on a detailed description of the collected empirical material, and only then should we formulate theoretical statements (Konecki, 2000, pp. 26-27). Nevertheless, the theoretical knowledge and information regarding the explored environment which were held by the researcher before commencing the research work may prove to be helpful in later stages, serving as comparable data and clues during the theoretical selection of samples, among others (Strauss \& Corbin, 1990, pp. 48-56; Glaser, 1978, p. 67).

In the case of research into intellectual disability, the limitation of the initial theoretical assumptions allowed me to maintain cognitive openness without following the discoveries made by other researchers (Niedbalski, 2013). Therefore, maintaining serendipity, continuously following the trace of new, previously unknown facts proved to be successful (cf. Strauss \& Corbin 1990, Glaser 1978). The requirement to limit pre-conceptualization protected me from becoming incorporated into established schemes. These may make the researcher follow specific paths of data interpretation, reproducing commonly shared, but not always correct, opinions. As a consequence, they could have become a weight, eliminating the opportunity to discover previously unknown phenomena or the possibility to look at an already raised notion from a different, new perspective (Niedbalski, 2009, p. 205). In the research into intellectual disability, the adopted recommenda- 
tions to limit pre-conceptualization allowed freedom of action and flexibility in following the discovered phenomena that appear during the course of the research (cf. Frankfort-Nachmias \& Nachmias, 2001, p. 313). Thanks to this, it was possible to see and describe such issues as the analysis of communication functions, the reconstruction of biographies of the residents, or negotiating dimensions of interpersonal relationships which were not considered to be a potential sub-sphere of the research topic in the initial phase of research.

\section{COLLECTING EMPIRICAL DATA IN THE CONTEXT OF THE SPECIFICITY OF INTELLECTUAL DISABILITY}

Another issue and, at the same time, a specific challenge that a researcher interested in issues of intellectual disability must be aware of is the potential difficulty related to collecting empirical data, which arises directly from the individuals' psycho-physical limitations. Although this problem affects not only this group of subjects, in this case, it may be extreme (Niedbalski, 2009, p. 207).

While the source of the problem lies in psycho-physical limitations - which significantly hinders research with intellectually disabled individuals - it also includes limited communication competence, understood here as them being able to interact with their surroundings, respond to stimuli, or express their needs (Parchomiuk, 2019, p. 80). These difficulties may be considered on several levels. The first one regards the "technical" difficulty of using verbal or non-verbal speech for physiological reasons, e.g., because of body deformations, distortions of voice channels, or damage to the particular parts of the brain responsible for speech (Minczakiewicz, 2000, p. 68). The second reason for communication limitations is due to the lack of ability to use and recognize the symbolic sense of written and spoken symbols, including gestures and body language (see: Smyczek \& Szwiec, 2000, pp. 22-23). Thirdly, a reason for difficulties in communication is the limited competencies regarding abstract thinking, which prevents a reflexive position towards the actions and behaviors of themselves and other individuals from the environment of the intellectually disabled (see: Piszczek, 2001, pp. 2-5).

A problem in understanding an intellectually disabled person results from the difficulties in interpreting this individual's behavior, which may be both a kind of message bearing particular content and an expression of unintentional and uncontrolled stereotypes (Reichmann, 2006, p. 4). The ability to communicate with intellectually disabled people and the possibility to understand them require individual treatment, appropriate to the speaker's linguistic and communicational competences (Żyta, 2011, pp. 24-25; see: Frankfort-Nachmias \& Nachmias, 2001, p. 225). 
Taking the above-mentioned difficulties into account, and with the need for an individual approach to the interviewees, it seems doubtful that research tools can be used with a high degree of standardization, or even interpretative "standards" for the behaviors of the intellectually disabled interviewees. This is pointed out by Monika Parchomiuk (2019, p. 75) who claims that "research using scales and questionnaires is burdened with many problems that may result from the cognitive, emotional and social functioning of respondents”. According to the mentioned author, limitations in the understanding of concepts, words and phrases may be crucial in this context, as well as difficulties related to the use of a multi-level response scale, or even reading and writing problems, which may limit self-filling of questionnaires (Parchomiuk, 2019, p. 76). It, therefore, forces the researcher to adopt a certain attitude and strategy for performing research and collecting empirical materials, characterized by significant flexibility (see: Silverman, 2007, p. 53). Grounded theory methodology brings such an opportunity, giving the researcher the right to use various materials and allowing him to collect data samples for analysis and interpretation regardless of their degree of standardization (Glaser \& Strauss, 1967, p. 45). Hence, by adopting the grounded theory methodology, we often reach for research techniques such as observation and (narrative, unstructured, etc.) interviews. When I talk about techniques, I mean those which are standardized, at least to some extent, although this standardization may vary. A separate group for me will be those empirical materials which cannot be directly qualified to any of the known data collection techniques, but due to the principles which exist in the grounded theory methodology that say that each type of information is a potential source of knowledge (all is data), they will be an equal means of describing, analyzing and interpreting the researched phenomena (Glaser \& Strauss, 1967).

In the research conducted in the environment of the intellectually disabled residents of a social welfare home, these techniques of acquiring empirical material (namely participant observation and unstructured interviews) were used. Among them, observing the behavior of intellectually disabled people, their relationships with the carers, as well as the ways of establishing contact and building understanding between the residents and staff, were particularly important. They made it possible to obtain some difficult information or information that was inaccessible by other means. Acquiring this information was, in fact, strictly dependent on several factors, which, in a way, dictated the need to choose specific data collection tools and the way they were used. Together, they formed a set of conditions that defined the nature of the research process and the strategy developed for research on intellectually disabled people (cf. Ramik-Mażewska, 2018, p. 119). 
The research used undisguised participant observation, where the identity of the researcher was known to both the personnel and residents of the welfare home. According to Krzysztof Konecki, this observation technique

makes it possible to access interaction episodes and events directly, [...] limiting the degree of the researcher's interference with the researched reality. But of course, this interference cannot be completely avoided. It is impossible to stand totally outside a researched social reality (Konecki, 2000, p. 144).

Using the participant observation technique in research has consequences - not only of a methodological nature but also related to the psychological and ethical aspects which the researchers themselves become entangled with (Frankfort-Nachmias \& Nachmias, 2001, p. 90). Ethical dilemmas in the case of observations $^{6}$ conducted in a social welfare home for intellectually disabled residents included the question of the permissible level of interference in the subjects' lives, and maintaining an interaction advantage over the subjects of the observations (cf. Babbie, 2006, pp. 312-313).

However, it should be stressed that regardless of the undisguised attitude of the observer, they were usually "unrecognizable" for the intellectually disabled charges of the social welfare home. This was due to their limited perceptive abilities and interpretation difficulties regarding the surrounding reality, which made it difficult for the residents to evaluate the researcher-observer status (Niedbalski, 2013). Despite the researcher's intention to stay undisguised as to their identity and open towards the undertaken actions, it became impossible to fulfill those conditions. This was not due to reasons attributable to the observer but to the researched individuals. Despite these difficulties, the use of the observation technique seems to be justified in this context because it provides the researcher with a possibility to observe the actual social behaviors of individuals during the course of events, and their spontaneous actions in the natural environment in which they function (Chomczyński, 2006, pp. 78-79).

Another way to obtain empirical data, apart from participant observation, was the use of unstructured interviews with the personnel of the welfare facility. This is a data collection technique based on a direct act of communication, which may take the form of a more or less directed dialog. The participation of the interviewer mainly comes down to the role of a listener, and the respondent becomes a speaker (cf. Babbie, 2006, p. 328). Also, in this case, the nature of the

6 I applied participant observation when researching the environment of the intellectually disabled, where the identity of the researcher was undisguised for the personnel and the residents of the social welfare home (cf. Frankfort-Nachmias \& Nachmias, 2001, p. 303). 
obtained data and the way they are processed may be related to the specificity of the intellectually disabled individuals, and it gave me a chance to reflect on the interviewees' perceptive possibilities, communication competencies, and the ability of abstract thinking (Niedbalski, 2013; cf. Żyta, 2011, p. 24). The attempt to carry out the interviews with the residents proved very difficult in practice, which was a consequence of the communication limitations and problems in establishing contact with the intellectually disabled people (cf. Parchomiuk, 2019, p. 81). As Beata Cytowska emphasizes (2012, p. 153), conducting interviews with people with intellectual disabilities requires increased attention from the researcher because it is necessary to follow a difficult to understand, often interrupted and inconsistent statement of the interlocutor. Therefore, according to the all is data principle, it was assumed that random conversations and dialogs heard in natural, everyday life situations, and the free expressions of the residents not induced by the researcher, may also serve as empirical material. This is a form of so-called conversational interviews, i.e., informal, private conversations, where encouraging, suggesting, humor, and postponing a conversation are acceptable tactics of collecting information (Konecki, 2000, p. 150).

In practice, a decision was made on using the empirical data collected with non-standard techniques, which was a direct consequence of the limited possibilities of the intellectually disabled individuals, or more precisely, their previously mentioned communication skills. Such a flexible approach in using the collected materials was possible thanks to the grounded theory methodology, which made it possible to collect data samples for analysis and interpretation regardless of their level of standardization (see: Cytowska, 2012, p. 162). This strategy seems particularly useful when researching intellectual disability (from the interaction perspective that is of interest for me), because it eliminates the limitations of methods which, while offering a high level of standardization, make it impossible to adjust the data collection tools to the possibilities of the researched people (see: Niedbalski, 2013). Therefore, a general observation can be made on this basis that the usefulness of a given research method and technique will be rooted in what is in our area of interest, and the selection should directly arise from the theoretical perspective adopted by the researcher.

It should also be noted that the issues presented above concerning the difficulty of collecting empirical data, as well as the participation of the researcher in the community of people with intellectual disabilities, do not exhaust the entire complexity of the issues presented. First of all, however, it was pointed to those aspects of research with participation of persons with intellectual disability which, firstly, involved the personal experiences of the author of this paper, and secondly, 
those which were clearly outlined in the context of research conducted with the grounded theory methodology and selected research techniques and tools.

\section{DATA TRIANGULATION - THE SYNERGY EFFECT IN THE RESEARCH PROCESS}

Differentiating the data sources adopted in the research into the intellectually disabled residents of a social welfare home results from adopting the triangulation procedure (Denzin, 1978). The research made use of data triangulation, ${ }^{7}$ which was an answer to the problem of obtaining direct information from disabled people. Thus, apart from interviews, the researcher turned to observation and existing data (brochures, chronicles, regulations, statutes, etc.) in their fieldwork. Thanks to the use of various research techniques, we can distance ourselves from the empirical materials - and this is particularly important in the case of field research, where, to some extent, the researcher is a participant of the phenomena under analysis (Konecki, 2000, p. 85). This was the case with the research conducted by the author, where the triangulation procedure proved to be helpful in protecting against excessive emotional involvement when dealing with the intellectually disabled individuals. Triangulation made it possible to exclude (or at least limit) any possible errors caused by the researcher losing objectivity within the environment of intellectually disabled individuals as they became entangled in the world of interpersonal relationships with the participants (Konecki, 2000, p. 85). A researcher often becomes a direct participant of events which originally had only an exploratory dimension. They are subjected to various influences from the researched environment, which often leave their mark in the psyche of the researcher-observer. ${ }^{8}$ This is what Piotr Chomczyński says about it:

along with the process of growing into a situational context, the researcher establishes more and more personal relationships with their surroundings. They become executors of actions resulting from the current interactions which they are active actors in, but they are also their co-creators. They are become objects of activity of the social actors to an increasingly greater degree, addressing particular contents and actions towards him. While subordinating himself to them, the researcher obtains a role of a member of a specific group [...] (Chomczyński, 2006, p. 72).

A danger of a participant-observer situation being shaped in this manner may be that they start to identify with the researched group, as suggested by Frankfort-

7 Norman Denzin (1978) distinguishes four types of triangulation: data, researcher, theoretical, and methodological.

8 Numerous authors raise this issue, warning against the deep emotional involvement of the researcher (Babbie, 2006, p. 315) and the danger of excessive contact with the subjects (Frankfort-Nachmias \& Nachmias, 2001, p. 118). 
-Nachmias and Nachmias (2001, p. 118) - the "nativization" of a researcher. The same authors (Frankfort-Nachmias \& Nachmias, 2001, pp. 307-308) suggest that to be able to counteract such circumstances, there is a need to separate oneself from those who are being researched; it may be achieved by applying proper procedures and research tools. Krzysztof Konecki (2000) believes that it is impossible for a researcher to distance himself fully from the observed objects, but it is also not advisable, in his opinion, as immersion in the human issues allows for a better and more proper understanding of the explored reality. He recommends that a researcher should try to maintain distance in the process of generating categories and writing down theoretical notes (Konecki, 2000, p. 152), and during field work, they might penetrate the researched area most deeply by adopting introspection and using their own emotions and the accompanying feelings. What is more, the author suggests that the possibility of maintaining this methodological "neutrality" towards the researched phenomena is provided by incorporating specific research procedures (Konecki, 2000, p. 153).

\section{PROCEDURES OF CONDUCT - WAYS TO ANALYZE AND INTERPRET DATA}

While making reference to the previous point (3.3), it needs to be stressed that in the case of the grounded theory methodology, the empirical data collection process takes place in stages or phases, but with parallel analysis and interpretation. The theory emerges here during the systematically conducted empirical research (Konecki, 2000, p. 26). Hence, the process of obtaining, analyzing, and interpreting the data is an integral part of the whole research process and takes place at the same time when particular methodological procedures are employed. What is important is that using those procedures means that the process of empirical data collection will not be done in a completely accidental or chaotic manner; it will be based on a pre-determined strategy of data selection, ordering the constantly gathered material. In this context, an especially important procedure that found its application in the research conducted by the author was the selection of appropriate cases. Grounded theory methodology offers the procedure of theoretical sampling, thanks to which the researcher, while collecting, coding and analyzing the materials, at the same time decides what data to gather and where (Glaser \& Strauss, 1967, p. 45). On encountering phenomena that are of interest during their fieldwork, the researcher may change the course and scope of their search, focusing their attention on aspects which they did not take into consideration previously or whose existence they were not aware of (Niedbalski, 2009, p. 212). Sampling is of a processual character and it takes place until theoretical saturation is achieved, i.e., up to the moment when no new data appears, and subsequent cases are similar 
to the previous ones, and they may be analyzed through the existing categories (Glaser, 1978, p. 142).

Another important GT methodology strategy is the constant comparative method. In their exploration of other data, the researcher attempts to choose cases that are both highly different but also similar to each other, to grasp the maximum number of conditions differentiating the presence of categories and their mutual correlations (Glaser \& Strauss, 1967).

In my research, I focused mostly on a single case study - a social welfare home for intellectually disabled women. However, it proved to be insufficient to limit myself to only this case (a single unit) in order to carry out an in-depth analysis of the problems and research. Therefore, I decided to research two other social welfare homes, of a slightly different profile. While still devoted to intellectually disabled individuals, they were characterized by a different structure of residents, determined by their sex. Hence, the fieldwork was carried out in three facilities, but each differed in the composition of the residents: in the first one, there were only women, in the second one, there were only men, while the third one was mixed (co-educational). In this way, I attempted to obtain the most faithful image of the analyzed phenomena and determine to what extent these phenomena are similar to each other despite them occurring in different facilities, and also to discover their specificity and source of differences. A comparison of the facilities showed that the similarities included the internal conditions and the legal, economic, and financial situation, etc. However, there were differences in terms of the sex structure of the residents, which, as it turned out during the research, has a direct influence on the behaviors inside the group, generating a unique environmental context. This is how it became possible to verify the previously obtained knowledge about the environment of the intellectually disabled individuals and to compare particular phenomena in relation to how they occur in different contexts.

The procedures of grounded theory methodology provide a possibility to separate the researcher from the direct "influence" of the experiences which are ascribed to them the moment they meet the subjects, hence providing an opportunity to form they own opinions, unburdened by preconceptions, evaluations of interpretations, or analyses. On the other hand, despite the difficulties of emotional tensions borne during the fieldwork, it is possible for the researcher to put himself in the shoes of the others. This provides him with a basis for deeper interpretations, and therefore a more accurate understanding of the events taking place in a given environment, and it allows him to discover the mechanisms that govern the behaviors of the participants (Lofland et al., 2009, p. 93). Thanks to the use of the procedures of grounded theory methodology, the researcher can apply the emo- 
tions that they feel when interpreting the observed phenomena, assuming that they feel the same way as the others, so they can attempt to understand the researched people through their emotions. The researcher-participant's emotions may point to what is important in the reality that they observe (Konecki, 2000, p. 154). A researcher that does not allow himself to feel any emotions automatically distances himself mentally from the people that are being researched. Therefore, they waste the opportunity provided by direct contact with the studied members of the given environment (Konecki, 2000).

In the case of research carried out in the environment of intellectually disabled individuals, I felt an emotional tension. On the one hand, it was directly connected with the disability of the members of that community, which triggered natural empathy. On the other hand, it was due to the constant feelings of uncertainty and anxiety. I was aware that I was a presence in a setting with unknown individuals who had unidentified intentions and uncontrolled motor activity, and with whom there was no direct contact. I felt disorientated and, in extreme cases, even in danger. This belief of the researcher about the "offensive attitude" of the intellectually disabled residents of the social welfare home was justified by common knowledge, and it was additionally intensified by stories told by the personnel, when they mentioned hazardous situations which had happened to them or to other people from that environment. ${ }^{9}$ The atmosphere in which the relationships between the researcher and the intellectually disabled subjects took place was initially dominated by high uncertainty situations. This means that it was difficult to correctly ascertain the intentions of the charges of the care facility. As a researcher, I often encountered problems with properly comprehending the symbols, gestures, and other forms of communication of the intellectually disabled. This created situations of misunderstanding, and at the same time, it increased my concerns about the real intentions of the residents. This, in turn, triggered a defensive attitude, which was initially made visible through limiting direct contact with the disabled, both in the form of keeping my distance from them, and a psychological barrier, which hindered the development of interpersonal relationships with the subjects (Niedbalski, 2013).

On the other hand, the emotions experienced by me and my involvement in the data collection process were a remedy, in some way, for the problems related to the psycho-physical limitations of the social welfare home charges, as they allowed for greater empathy with the situation of the subjects, even when direct understanding was hindered by the previously mentioned communication barriers (see:

9 Such actions created a kind of folklore of the personnel "society" of the welfare home, and it was used as an initiation ritual for every new team member (which I was also regarded as, to an extent), testing their mental toughness (cf. Konecki, 1992). 
Smyczek \& Szwiec, 2000, pp. 22-23). The ability to communicate with intellectually disabled people, and the possibility to understand them, made it necessary to treat them individually, in a way that was appropriate to their linguistic and communicational competences (see: Frankfort-Nachmias \& Nachmias, 2001, p. 225). This was possible, to a great extent, thanks to the use of "feeling" instead of verbal communication. The procedures of methodological correctness described above prevented me from becoming emotionally involved, which might have limited my objectivity in viewing the observed phenomena. Therefore, at the level of data collection (sampling), a researcher adopting the procedures of grounded theory methodology has a broader cognitive perspective as they may refer to a diverse spectrum of personal experiences (including the emotions they feel). By interpreting them, they gain a proper distance, which allows them to perform analyses that are not burdened with their own judgment.

\section{SUMMARY}

The usefulness of grounded theory methodology and interpretative sociology when researching intellectual disability was, to a large extent, due to the specificity of the explored environment, as the members have both limited possibilities to communicate or interact with their environment and limited interpretative skills. However, these difficulties should not affect the quality of the research or lead to its superficiality, and grounded theory methodology can be helpful with this (Niedbalski, 2009, p. 213). On the other hand, using grounded theory methodology allows a researcher to lean on their own experience, and the direct contact with the researched individuals gives an opportunity to discover what would be practically unattainable with quantitative methods. At the same time, the procedures of grounded theory provide specific strategies of action, giving the researcher the possibility to permanently verify and auto-correct the analyses of the empirical materials. Therefore, we obtain a whole array of tools that allow for the significant flexibility of the researcher, with the simultaneous possibility to continuously verify the process for the development of hypotheses and theories. Applying the grounded theory methodology in my research made it possible to discover phenomena such as the process of building agreements between the personnel and the residents, defining and self-defining intellectual disability (including its negotiating character), "organizational language”, characteristics of the process of socializing the residents and personnel, the strategy of dealing with the residents and ways of keeping the institutional order, and the meaning of fiction, 
fantasy and organizational legends, or creating the residents' biography (Niedbalski, 2009, p. 213). Therefore, the grounded theory methodology makes it possible to see things from the perspective of the social actors and grasp the processual dimension of the researched phenomena (Glaser, 1978, p. 11). Thanks to the liberal treatment of the data sources, it makes it possible for the researcher to lean on even the slightest piece of information which might prove to be especially important when the problems of the research pertain to phenomena that are difficult to be verified empirically, such as intellectual disability.

Taking the above considerations into account, it can be concluded that the following arguments favor incorporating a qualitative approach into research performed in the environment of intellectually disabled individuals. Firstly, the research concerned a sphere of social reality which would be hard to measure through statistics, and exploring this world with the use of quantitative methods seemed limited. Secondly, qualitative research allows for a deeper understanding of particular phenomena, as it takes into account the social and cultural contexts (Silverman, 2007, p. 56). In the case of research into intellectual disability, it is a gateway to interpretations, without imposing arbitrary explanations (Silverman, 2007, p. 58; cf. Ramik-Mażewska, 2004, pp. 402-410). Thirdly, in order to understand all the interactive phenomena we cannot eliminate the qualitative approach (Kacperczyk, 2005, p. 144). In the words of Anna Kacperczyk (2005, p. 144), "although quantitative analysis provides valuable information about the scale of the phenomenon and differences in the intensity of certain features, it is only qualitative analysis that makes it possible to capture the essence of the phenomenon under study”. Fourthly, comprehending phenomena in their interactional perspective requires long-term and direct contact with the subjects, which is not offered by the quantitative research (Silverman, 2007, p. 58). Fifth of all, the qualitative research gives an opportunity to adopt the narrative subject's perspective, at the same time showing the researched fragment of the social world as a resultant of different people's perspectives, and this allows to reconcile scientific objectivity with the subjectivity of the presented stories of individuals and the one-sidedness of the individual's view with the multithreadedness of social reality (Wołowicz-Ruszkowska, 2013, p. 128). Sixthly and finally, qualitative methods offer a flexibility which is difficult to achieve with quantitative methods, also in the course of research (Silverman, 2007, p. 53). According to Anna Kacperczyk, since

fixed instruments for obtaining quantitative data make it possible to [...] operate in the area of data generated in a planned manner [...], the qualitative data are open, revealing the shades, nuances, and multidimensionality of the studied phenomena (2005, p. 143). 


\section{References}

Babbie, E. (2006). Badania społeczne w praktyce. Warszawa: Wydawnictwo Naukowe PWN.

Becker, H. (1953). Becoming a marihuana user. American Journal of Sociology, 59, pp. 235242.

Becker, H. (1963). Outsiders: Studies in the Sociology of Deviance. New York: The Free Press of Glencoe.

Becker, H., Geer, B., Hughes, E.C., \& Strauss, A. (1961). Boys in White. Chicago: University of Chicago Press.

Blumer, H. (1969). Symbolic Interactionism: Perspective and Method. Englewood Cliffs, NJ: Prentice Hall.

Charmaz, K. (1994). Grounded Theory. Objectivist and Constructivist Methods. In: N. Denzin, \& Y.S. Lincoln (Eds.), Handbook of Qualitative Research (pp. 507-535). Thousand Oaks, CA: Sage Publications.

Chomczyński, P. (2006). Wybrane problemy etyczne w badaniach. Obserwacja uczestnicząca ukryta. Przegląd Socjologii Jakościowej, 2(1), pp. 68-87.

Cytowska, B. (2012). Trudne drogi adaptacji. Wqtki emancypacyjne w analizie sytuacji dorosłych osób z niepełnosprawnościq intelektualnq we współczesnym społeczeństwie polskim. Kraków: Oficyna Wydawnicza Impuls.

Danforth, S., \& Navarro, V. (1998). Speech Acts: Sampling the Social Construction of Mental Retardation in Everyday Life. Mental Retardation, 36(1), pp. 31-43. DOI: 10.1352/00476765(1998)036<0031:SASTSC>2.0.CO;2.

Denzin, N. (1972). The Research Act. In: J.G. Manis, \& B.N. Meltzer (Eds.), Symbolic Interactionism: A Reader in Social Psychology ( $2^{\text {nd }}$ Ed.) (pp. 76-91). Boston: Allyn and Bacon, Inc.

Denzin, N. (1978). The Research Act: A Theoretical Introduction to Sociological Methods. New York: McGraw-Hill.

Ferguson, Ph.M., Ferguson, D.L., \& Taylor, S.J. (1992). Introduction: Interpretivism and Disability Studies. In: P.M. Ferguson, D.L. Ferguson, S.J. Taylor (Eds.), Interpreting Disability: A Qualitative Reader (pp. 15-35). New York-London: Teachers College, Columbia University.

Flick, U. (2010). Projektowania badania jakościowego. Warszawa: PWN.

Frankfort-Nachmias, Ch., \& Nachmias, D. (2001). Metody badawcze w naukach społecznych. Poznań: Wydawnictwo Zysk i S-ka.

Glaser, B.G. (1978). Theoretical Sensitivity: Advances in the Methodology of Grounded Theory. San Francisco: University of California.

Glaser, B.G., \& Strauss, A.L. (1967). The Discovery of Grounded Theory: Strategies for Qualitative Research. Chicago: Aldine.

Goffman, E. (1963). Behavior in Public Places: Notes on the Social Organization of Gathering. New York: The Free Press of Glencoe.

Goffman, E. (2008). Zachowania w miejscach publicznych. O społecznej organizacji zgromadzeń. Warszawa: PWN.

Hałas, E. (2005). Jakie nowe zasady metody socjologicznej? O wielości socjologii interpretacyjnych. In: J. Leoński, \& A. Kołodziej-Durnaś (Eds.), W kręgu socjologii interpretatywnej-zastosowanie metod jakościowych (pp. 7-25). Szczecin: Economicus. 
Hammersley, M., \& Atkinson, P. (2007). Ethnography: Principles in Practice ( ${ }^{\text {rd }}$ Ed.). London: Routledge.

Kacperczyk, A. (2005). Zjawiska społeczne w zwierciadle metod ilościowych i jakościowych. In: J. Leoński, \& A. Kołodziej-Durnaś (Eds.), W kręgu socjologii interpretatywnej - zastosowanie metod jakościowych (pp. 122-143). Szczecin: Economicus.

Konecki, K. (1992). Nowi pracownicy a kultura organizacyjna. Studium folkloru fabrycznego. Łódź: Wydawnictwo Uniwersytetu Łódzkiego.

Konecki, K. (2000). Studia z metodologii badań jakościowych. Teoria ugruntowana. Warszawa: Wydawnictwo Naukowe PWN.

Lofland, J., Snow, D.A., Anderson, L., \& Lofland, L.H. (2009). Analiza układów społecznych. Przewodnik metodologiczny po badaniach jakościowych. Warszawa: Wydawnictwo Naukowe Scholar.

Minczakiewicz, E. (2000). Kształtowanie umiejętności komunikacyjnych dzieci głębiej upośledzonych. Szkoła Specjalna, 2-3, pp. 67-75.

Niedbalski, J. (2009). Niepełnosprawność intelektualna w perspektywie badań socjologicznych. Rozważania nad zastosowaniem metod jakościowych. In: A. Bąk, \& Ł. Kubisz-Muła (Eds.), Metody, techniki i praktyka badań społecznych (pp. 199-216). BielskoBiała: ATH w Bielsku-Białej.

Niedbalski, J. (2013). Żyć i pracować w domu pomocy społecznej. Socjologiczne studium interakcji personelu z upośledzonymi umysłowo podopiecznymi. Łódź: Wydawnictwo UŁ.

Parchomiuk, M. (2019). Badania z udziałem osób niepełnosprawnych intelektualnie. Problemy metodologiczne i etyczne. Roczniki Pedagogiczne, 11(3), pp. 73-95. DOI: 10.18290/ rped.2019.11.3-5.

Piszczek, M. (2001). Metody komunikacji alternatywnej i wspomagającej w edukacji dzieci głębiej upośledzonych umysłowo i autystycznych. Część II. Rewalidacja, 1, pp. 3-21.

Podgórska-Jachnik, D. (1995). Nowe tendencje w pedagogice specjalnej wobec emancypacji środowisk niepełnosprawnych. In: B. Śliwierski (Ed.), Pedagogika alternatywna - dylematy teorii (pp. 369-378). Łódź-Kraków: Oficyna Wydawnicza Impuls.

Podgórska-Jachnik, D. (2014). Praca socjalna z osobami z niepełnosprawnościq i ich rodzinami. Warszawa: Centrum Rozwoju Zasobów Ludzkich.

Ramik-Mażewska, I. (2004). Integracja społeczna osób niepełnosprawnych intelektualnie w środowisku życia. In: G. Dryżałowska, \& H. Żuraw (Eds.), Integracja społeczna osób niepełnosprawnych (pp. 402-410). Warszawa: Wydawnictwo Naukowe Żak.

Ramik-Mażewska, I. (2018). Style życia kobiet z niepełnosprawnościq intelektualnq. Studium socjopedagogiczne. Warszawa: Wydawnictwo Naukowe FREL.

Reichmann, W. (2006). Niebezpieczne, niezrozumiane. Stereotypie ruchowe i zachowania o charakterze natręctw u osób niepełnosprawnych intelektualnie oraz autystycznych. Wspólne Tematy, 10, pp. 3-13.

Rzeźnicka-Krupa, J. (2009). Niepełnosprawność i świat społeczny. Szkice metodologiczne. Kraków: Oficyna Wydawnicza Impuls.

Silverman, D. (2007). Interpretacja danych jakościowych. Warszawa: Wydawnictwo Naukowe PWN.

Smyczek, A., \& Szwiec, J. (2000). Metodyka nauczania alternatywnych sposobów porozumiewania się i techniki posługiwania się symbolami. Rewalidacja, 1, pp. 21-26. 
Söder, M. (1989). Disability as a Social Construct: The Labelling Approach Revisited. European Journal of Special Education Needs, 4(2), pp. 117-129.

Strauss, A.L., \& Corbin, J. (1990). Basics of Qualitative Research. London-New Delhi: Sage.

Strauss, A.L., Schatzman, L., Bucher, R., Ehrlich, D., \& Melvin, S. (1964). Psychiatric Ideologies and Institutions. New York: Free Press of Glencoe.

Wołowicz-Ruszkowska, A. (2013). Zanikanie. Trajektorie tożsamości kobiet z niepełnosprawnościq. Warszawa: Wydawnictwo Akademii Pedagogiki Specjalnej.

Zakrzewska-Manterys, E. (2003). Dziecko upośledzone - nieuchronność stereotypu. In: A. Gustavsson, J. Tossebro, \& E. Zakrzewska-Manterys (Eds.), Niepełnosprawność intelektualna a style życia. Perspektywy podmiotowe, wybory życiowe, systemy usług w Szwecji, Norwegii i w Polsce (pp. 89-118). Warszawa: Wydawnictwo IFiS PAN.

Zakrzewska-Manterys, E., \& Gustavsson, A. (Eds.) (1997). Upośledzenie w społecznym zwierciadle. Warszawa: Wydawnictwo Naukowe Żak.

Żółkowska, T. (2004). Wyrównywanie szans społecznych osób z niepełnosprawnościq intelektualnq. Uwarunkowania i obszary. Szczecin: Oficyna IN PLUS.

Żuraw, H. (2014). Opcje antropozoficzne w pedagogicznych studiach jakościowych nad problematyką niepełnosprawności i osób niepełnosprawnych w perspektywie teorii ugruntowanej. Przegląd Badań Edukacyjnych, 18, pp. 143-170. DOI: 0.12775/PBE.2014.011.

Żyta, A. (2011). Życie z zespołem Downa. Narracje biograficzne rodziców, rodzeństwa i dorosłych osób z zespołem Downa. Kraków: Oficyna Wydawnicza Impuls. 